bệnh lý trên một bệnh nhân 42,85\% bênh nhân có ít nhất 1 bệnh kèm theo, 23,81\% có 2 bệnh, $9,53 \%$ có 3 bệnh kèm theo, số bệnh nhân có từ 2 bệnh trở lên thì bệnh kèm theo thường là cao huyết áp. Nghiên cứu của tác giả Cao Thi (2014) số bệnh nhân có bệnh nội khoa kết hợp chiếm $49 \%$, bao gồm bệnh tịm mạch $(28,8 \%)$, đái tháo đường $(8,4 \%)$, tai biến mạch máu não (11,9\%), bệnh tim mạch kết hợp với đái tháo 59 đường (5,19\%).

4.1 Đánh giá kết quả phục hôi chức năng vận động sau phâu thuật và một số yếu tố liên quan. Kết quả Phục hồi chức năng vận động thời điểm 1 tháng, 3 tháng và 6 tháng (Theo thang điểm Harris)

Một số yếu tố liên quan đến phục hồi chức năng vận động

4.2 Đánh giá chất lượng cuộc sống sau phẫu thuật và một số yếu tố liên quan. Đánh giá chất lượng cuộc sống sau phẫu thuật. Một số yếu tố liên quan

\section{KẾT LUẬN}

- Kết quả phục hồi chức năng vận động loại tốt và rất tốt tăng dân từ 1 tháng là $1,2 \%$ đến 3 tháng là $41,6 \%$ và đến 6 tháng là $75 \%$ và ngược lại kết quả trung bình kém giảm dân từ $98 \%$ tháng 1 xuống $58,39 \%$ tháng thứ 3 và còn $24,79 \%$ tháng thứ 6 . Kết quả tốt và rất tốt gặp chủ yếu ở nữ, 60-69 tuổi, có bệnh đi kèm, Garden 3,4.

- Kết quả điểm số chất lượng cuộc sông khá tốt và tốt của bệnh nhân tăng dân ở các thời điểm đánh giá 1 tháng $(0 \%), 3$ tháng $(2,4 \%)$ và 6 tháng (47,6\%). Chất lượng cuộc sống khá tốt và tốt tập trung vào các đối tượng nữ, <70 tuổi, có bệnh đi kèm, Garden 3 và 4 .

\section{TÀI LIÊU THAM KHẢO}

1. Lưu Văn Hựề, (2016), Nghiên cứu chất lượng sống sau mổ thay khớp háng bán phân ở bểnh nhân lớn tuổi, Luận án chuyên khoa cấp 2, Đại học $Y$ dược TPHCM.

2. Nguyễn Văn Khanh, (2019), Nghiên cứu đặc điểm lâm sàng, cận lâm sàng, nguyên nhân và đánh giá kết quả điều tri gãy cổ xương đùi bằng thay khớp háng bán phẩn tại Bệnh viện Trường Đại học Y Dược Cân Thơ năm 2018-2019, Luận án chuyên khoa cấp 2, Đại học Y dược Cần Thơ.

3. Nguyễn Tường Quàng (2012), Đánh giá kết quả phâuu thuật thay khớp hàng bán phần lưỡng cực điều trị gãy mới cổ xương đưi do chấn thương ở bệnh nhân cao tuổi, Luận án chuyên khoa cấp 2, Đại học Y dược TPHCM.

4. Trân Quang Sớn, (2017), Nghiên cứu đặc điểm lâm sàng, cận lâm sàng và đánh giá kết quả điệu trị gãy cổ xương đùi ở người cao tuổi bằng phẫu thuất thay khớp háng bán phân không xi măng tai Bệnh viện Trương Đại học Y Dược Cần Thơ, Luận vắn bác sĩ nội trú, Trường Đại học Y Yược Cần Thớ.

5. WHO (1998), The World Health Organization Quality of Life Assessment (WHOQOL): Development and general psychometric properties. Soc Sci Med. 46(12), pp 1569-1585.

6. Ware J E, Jr. and Sherbourne C D (1992), The MOS 36- item short-form health survey (SF36). I Conceptual framework and item selection. Med Care. 30(6), pp 473-483

7. Han S K, Song H S, Kim R, Kang S H, (2016), "Clinical results of treatment of garden type 1 and 2 femoral neck fractures in patients over 70-year old", Eur J Trauma Emerg Surg, 42 (2), pp. 191-196.

8. Mellner $C$, Eisler $T$, Knutsson $B$, Mukka $S$, (2017), "Early periprosthetic joint infection and debridement, antibiotics and implant retention in arthroplasty for femoral neck fracture", Hip Int, 27 (4), pp. 349-353.

\title{
KẾT QUẢ PHẪU THUÂ̂T U NGUYÊN BÀO TUỶ TẠI BỆNH VIỆN HỮU NGHỊ VIỆT ĐỨC
}

\section{TÓM TẮT}

Bao gồm 53 bệnh nhân được phẫu thuật u nguyên bào tuỷ tại bệnh viện Việt Đức, có kết quả mô bệnh học, giai đoạn 9/2016 đến 9/2019. Tuổi từ $02-43$, tuổi trung bình $13,66 \pm 11,52$. Tỷ lệ Nam / Nữ = 1,52/ 1. Đau đầu gặp ở $83 \%$. Trên cộng hưởng từ $17 \%$ nằm ở bán câu tiểu não, $83 \%$ nằm ở thuỳ nhộng. Kích

*Trường đại hoc Y Hà Nội

Chịu trách nhiệm chính: Phạm Thanh Tuân

Email: drtuanneurovn@gmail.com

Ngày nhận bài: 22.10.2021

Ngày phản biện khoa họ: 20.12.2021

Ngày duyệt bài: 29.12.2021
Phạm Thanh Tuân*

thước u 30 - 50 mm chiếm 81,13\%. Điểm Karnofsky trước mổ trung bình $85,68 \pm 12,21$. U mât độ mềm chiém $81,14 \%$, giàu mach $83 \%$. Mức độ lấy u toàn bộ ( GTR ) $73,6 \%$, gân toàn bộ (NTR ) 24,52\%. Tuỳ vào kích thước u mà thời gian phấu thuật ở từng nhóm là khác nhau. Lượng máu truyên trong mổ từ $250 \mathrm{ml}$ tới $1050 \mathrm{ml}$. Không có biến chứng sau mổ $69,86 \%$, các biến chứng khác cũng gặp với tỉ lệ $3-9 \%$. Điểm GOS sau mổ ở đô 1 , 2 chiếm $83 \%$, đô 3 chiếm $9,46 \%$, đô 4 chiếm 7,54\%. U nguyên bào tuỳ là u não ác tính độ 4 theo WHO. Kích thước khối u > 30mm, tâp trung chủ yếu ở thuỳ nhộng. Kết quả GOS sau phẩu thuật ở độ 1,2 chiếm $83 \%$, độ 3 chiếm $9,46 \%$ và độ 4 chiếm $7,54 \%$.

Tư khoá: u nguyên bào tuỷ, Karnofsky, GOS, biến chứng. 


\section{SUMMARY \\ RESULT SURGERY OF MEDULLOBLASTOMA IN VIET DUC HOSPITAL}

Total 53 patients medulloblastoma surgery in Viet Duc hospital with histopathological results, from 9/2016 to 9/2019. Age from 02 - 43, mean age 13.66 \pm 11.52 . Male/Female ratio $=1.52 / 1$. Headache occurred in $83 \%$. MRi, $17 \%$ in the cerebellar hemisphere, $83 \%$ in cerebella vermis. Tumor size 30 $50 \mathrm{~mm}$ was $81.13 \%$. The mean preoperative Karnofsky score was $85.68 \pm 12.21$. Soft density tumors $81.14 \%$, rich in vessels $83 \%$. Gross Total Rececion (GTR) $73.6 \%$, Near Total Resection (NTR) $24.52 \%$. blood transfusion Intraoperative ranges from $250 \mathrm{ml}$ to $1050 \mathrm{ml}$. There were no complications after surgery $69.86 \%$, other complications were $3-9 \%$. GOS score after surgery at grade 1 and 2 accounted was $83 \%$, grade 3 accounted was $9.46 \%$, grade 4 accounted was $7.54 \%$. Medulloblastoma is a grade 4 brain tumor according to WHO. Tumor size $>30 \mathrm{~mm}$, almost in cerebella vermis. GOS results after surgery at grade 1,2 accounted was $83 \%$, grade 3 was $9.46 \%$ and grade 4 was $7.54 \%$.

Keywords: Medulloblastoma, Karnofsky, GOS, complications.

\section{I. ĐĂT VẤN ĐỀ}

U nguyên bào tủy (Medulloblastoma) là một thuật ngữ chuyên ngành để chỉ các khối u tiên phát ác tính trong tiểu não. U phát triển từ các nguyên bào thần kinh có nguồn gốc từ ống thần kinh trong giai đoạn phôi thai. ${ }^{1}$

Theo phân loại của WHO 2007, WHO 2016 thì đây là loại u ác tính độ IV, có thể gặp ở mọi lứa tuổi nhưng gặp nhiều hơn ở độ tuổi < 16 tuổi với hơn $80 \%$ số ca mắc.

U nguyên bào tủy chiếm $4-10 \%$ các u não và chiếm $20-25 \%$ số u não trẻ em. Nam gặp nhiều hơn nữ với tỷ lệ nam/nữ khoảng $2 / 1 .^{2}$

Tần suất mắc ở khu vực châu Âu và bắc Mỹ là $5-7 / 1$ triệu trẻ. Ở Pháp tần suất mắc bệnh trẻ em là $6,4 / 1$ triệu trẻ/năm. Ở Mỹ hàng năm có khoảng 250 - 300 ca bệnh u nguyên bào tủy được phát hiên. ${ }^{3}$

Độ tuổi thường gặp ở trẻ là 6,2 tuổi, ở người lớn là 25,5 tuổi.

Chẩn đoán và điều trị bệnh lý này chỉ được tiến hành tại các trung tâm y học lớn ở Hà Nội hặc thành phố Hồ Chí Minh bằng phẫu thuật lấy bỏ khối u và kết hợp hoá xạ trị liệu. Để hiểu sâu hơn và góp phần đánh giá toàn diện hơn về bệnh lý nặng nề này và có thể đưa ra những khuyến nghị trong công tác chẩn đoán và tiên lượng điều trị.

Vì vậy chúng tôi tiến hành ngiên cứu đề tài: "Đánh giá kết quả phẫu thuật u nguyên bào tuỷ tại bệnh viện Việt Đức". Với mục tiêu:
1. Đánh giá kết quả phẫu thuật u nguyên bào tuỷ tại bệnh viện Việt Đức.

2. Mồ tá các biến chứng nặng trong phẫu thuật u nguyên bào tuý.

\section{II. ĐỐI TƯỢNG VÀ PHƯƠ'NG PHÁP NGHIÊN CỨU}

Thiết kế nghiên cứu: Nghiên cứu của chúng tôi là nghiên cứu mô tả. Chúng tôi lấy cỡ mẫu theo phương pháp thuận tiện. Bao gồm các bệnh nhân được phẫu thuật tại Trung tâm phẫu thuật Thần Kinh bệnh viện Việt Đức có kết quả là u nguyên bào tuỷ.

Đối tượng nghiên cứu: Đối tượng nghiên cứu gồm 53 bênh nhân được chẩn đoán và điều trị phẫu thuật kết hợp cùng chẩn đoán mô bệnh học là u nguyên bào tuỷ với hồ sơ nghiên cứu đẩy đủ, rõ ràng trong thời gian từ 09.2016 đến 09.2019.

Các chỉ tiêu nghiên cứu được thu thập theo mẫu hồ sơ nghiên cứu.

Đặc điểm nghiên cứu: tuổi, giới, hình ảnh cộng hưởng từ, kết quả mô bênh học, điểm Karnofsky trước mổ, thời gian phẩu thuật, lượng máu truyền trong mổ, các biến chứng sau mổ: nhiễm trùng vết mổ, rò dịch não tuỷ, chảy máu sau mổ, chảy máu ngoài màng cứng, rối loạn điện giải, suy hô hấp, loét, diễn biến nặng. Điểm GOS sau mố, liên quan giữa biến chứng và điểm GOS sau mồ.

Xử lý số liệu: Các số liệu thu thập được tác giả lập phiếu nghiên cứu, xử lý số liệu trên phân mềm SPSS 22.0 với các thuật toán thống kê y học.

Đạo đức nghiên cứu: Tất cả các bênh nhân trong nhóm nghiên cứu được giải thích kỹ về tình trạng bệnh, quy trình phẫu thuật, các nguy cơ và biến chứng có thể xảy ra trong và sau phẫu thuật, và ký cam kết điều trị.

Phẫu thuật được thực hiện bởi nhóm phẫu thuật viên Thần kinh dày dạn kinh nghiệm tại Trung tâm phẫu thuật thần kinh Bệnh viện Việt Đức. Tất cả các thông tin bệnh nhân đều được giữ bí mật.

\section{KẾT QUẢ NGHIÊN CỨU}

Qua tiến hành nghiên cứu 53 bênh nhân được chẩn đoán u nguyên bào tuỷ và tiến hành phẩu thuật lấy u với chẩn đoán xác định mô bệnh học là u nguyên bào tuỷ. Chúng tôi thu được kết quả như sau.

Giới tính. Trong 53 ca bệnh có 32 trường hợp là nam giới, 21 trường hợp là nữ giới. Tî lệ Nam / Nữ $\approx 1,52$.

Nhóm tuổi mắc bệnh. Độ tuổi trong nghiên cứu này trải dài từ 2 tuổi đển 43 tuổi. Độ tuổi trung binh $12,12 \pm 9$ tuổi. 
$40 \%$

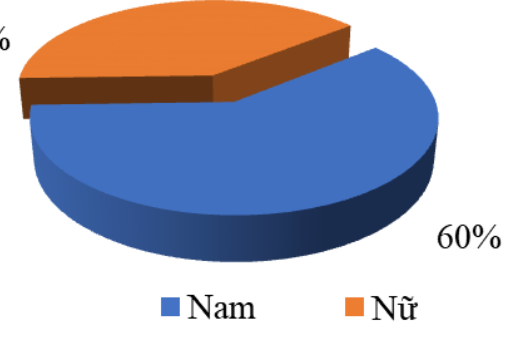

Biểu đồ 1: Biểu đồ giới tính

Vị trí u. U thường gặp ở thuỳ nhộng với 44 trường hợp chiếm $83 \%$. U nằm ở bán câu tiểu não chiếm $17 \%$ số trường hợp.

\section{Bảng 1: Vị trí khôi u}

\begin{tabular}{|c|c|c|}
\hline Vị trí & $\mathbf{n}$ & $\mathbf{\%}$ \\
\hline Thuỳ nhộng & 44 & 83 \\
\hline Bán câu & 9 & 17 \\
\hline Tống & $\mathbf{5 3}$ & $\mathbf{1 0 0}$ \\
\hline
\end{tabular}

Điếm Karnofsky trước mố

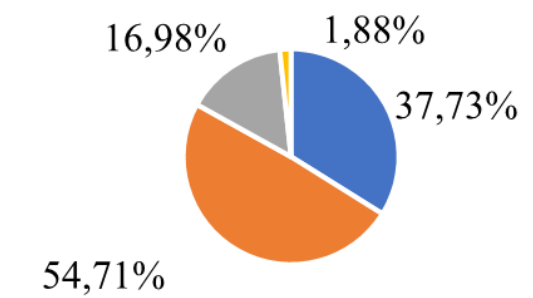

- 50-60 - 70-80 -90-100 $\square$ 10-40

Biểu đồ 2: Điểm Karnofsky trước mố

Điểm Karnofsky trung bình trước mổ là $85,68 \pm 12,21$.

Đa số bệnh nhân đến viện trong tình trạng toàn thân còn tốt với điểm Karnofsky trung bình 85,68 . Có $37,73 \%$ bệnh nhân đến viện trong tình trạng cân sự giúp đõ thường xuyên của người khác. Cá biệt có 1 trường hợp bệnh nhân vào viện trong tình trạng nguy kịch, phải hồi sức tích cực và mổ dẫn luu não thất cấp cứu.

Đắc điểm u trong mổ

Bảng 2: đăc điểm u trong mổ

\begin{tabular}{|c|c|c|c|}
\hline \multicolumn{2}{|c|}{ Đặc điểm } & $\mathbf{n}$ & $\mathbf{\%}$ \\
\hline \multirow{2}{*}{ Mật độ } & Chắc & 10 & 18,86 \\
\cline { 2 - 4 } & Mềm & 43 & 81,14 \\
\hline Mức độ tăng \\
sinh mạch máu & Giàu mạch & 44 & 83,00 \\
\cline { 2 - 4 } & İt mạch & 9 & 17,00 \\
\hline \multirow{2}{*}{ Ranh giới } & Không rõ & 14 & 26,42 \\
\cline { 2 - 4 } & Rõ & 39 & 73,58 \\
\hline
\end{tabular}

Nhânn xét: mật độ u trong mổ đa số là dạng mềm $(81,14 \%)$, giàu mạch máu $(83 \%)$, ranh giới rõ $(73,58 \%)$. Đây là những yếu tố quyết định tới việc phẫu thuật lấy bỏ hoàn toàn khối u.

Hình ảnh vi thể. Hình ảnh vi thể của $u$ nguyên bào tuỷ đa số là tế bào hình củ cà rốt, điếu xì gà $(81,14 \%)$. Tế bào u với nhân tròn nhỏ, ưa kiềm hoặc tế bào u nhân lớn, kiềm tính chiếm 9,43\%. Cấu trúc dạng hoa hông gặp 44/53 trường hợp (94,33\%). Tỉ lệ tế bào u quây quanh mạch chiếm tỉ lệ cao với 83,01\%.

Mức độ lấy bỏ u

Bảng 3: Mức độ lây u

\begin{tabular}{|c|c|c|}
\hline Nhóm & $\mathbf{n}$ & $\mathbf{\%}$ \\
\hline Lấy toàn bộ u (GTR) & 39 & 73,60 \\
\hline Lấy gânn hoàn toàn u (NTR) & 13 & 24,52 \\
\hline Lấy bán phần u (NTR) & 1 & 1,88 \\
\hline Tổng & $\mathbf{5 3}$ & $\mathbf{1 0 0}$ \\
\hline
\end{tabular}

Nhân xét: khả năng lấy toàn bộ u chiếm $73,60 \%$, lấy gân hoàn toàn chiếm $24,52 \%$, và có 1,88\% là lấy bán phân u.

Liên quan giữa kích thước u và mức độ lấy u

Bảng 4: Liên quan giữa kích thước u và mức độ lấy u

\begin{tabular}{|c|c|c|c|c|c|}
\hline \multirow{2}{*}{\multicolumn{2}{|c|}{ Mức độ lấy u }} & \multicolumn{3}{|c|}{ Kích thước u } & \multirow{3}{*}{$\begin{array}{c}\text { Tống } \\
39\end{array}$} \\
\hline & & \multirow{2}{*}{$\frac{<30 \mathrm{~mm}}{1}$} & \multirow{2}{*}{$\begin{array}{c}\mathbf{3 0 - 5 0 m m} \\
32 \\
\end{array}$} & \multirow{2}{*}{$\frac{>50 \mathrm{~mm}}{6}$} & \\
\hline & $\mathrm{n}$ & & & & \\
\hline loan bọ & $\%$ & 100 & 74,41 & 66,66 & 73,60 \\
\hline \multirow{2}{*}{ Gân toàn bộ } & $\mathrm{n}$ & 0 & 10 & 3 & 13 \\
\hline & $\%$ & 0 & 23,27 & 33,34 & 24,52 \\
\hline \multirow{2}{*}{ Bán phân } & $\mathrm{n}$ & 0 & 1 & 0 & 1 \\
\hline & $\%$ & 0 & 2,32 & 0 & 1,88 \\
\hline \multirow{2}{*}{ Tổng } & $\mathbf{n}$ & 1 & 43 & 9 & 53 \\
\hline & $\%$ & 100 & 100 & 100 & 100 \\
\hline
\end{tabular}

Nhận xét: trong nghiên cứu này chúng tôi thấy 1 trường hợp u nhỏ hơn $30 \mathrm{~mm}$ và được phẫu thuật lấy toàn bộ u. Trong nhóm u có kích thước $30-50 \mathrm{~mm}$ thì có $74,41 \%$ phẫu thuật lấy toàn bộ u, 23,27\% lấy gân toàn bộ u. Với nhóm u >50mm thì có $66,66 \%$ phẫu thuật lây toàn bộ u. Có 1 trường hợp lây u bán phân trong nghiên cứu này.

Dẫn lưu não thất. Trong nghiên cứu này chúng tôi thấy có 30,18\% số bệnh nhân dẫn lưu não thất trước mổ lấy u. Có $62,26 \%$ số bệnh nhân không dẫn lưu não thất. Có 3 trường hợp dẫn lưu não thất trong khi phẫu thuật lấy u. 2 trường hợp phải dẫn lưu não thất sau mổ lấy u. 
Thời gian phẫu thuật và thời gian nằm viện. Nghiên cứu có 1 trường hợp $u<30 \mathrm{~mm}$ được phẫu thuật lấy toàn bộ u trong thời gian 180 phút. Với nhóm u > 50mm thì thời gian phẫu thuật lấy u trung bình là 272 phút \pm 141 . Nhóm u có kích thước $30-50 \mathrm{~mm}$ thì thời gian phẫu thuật trung bình là 205 phút \pm 112 .

Thời gian nằm viện sau phẫu thuật trong nghiên cứu này trong phân nhóm u có kích thước $30-50 \mathrm{~mm}$ là 10,06 ngày $\pm 6,24$.

ở nhóm $u>50 \mathrm{~mm}$ thời gian nắm viện sau mổ là $14 \pm 8,4$.

Có 1 trường hợp $\mathrm{u}<30 \mathrm{~mm}$ có thời gian nằm viện sau mổ là 8 ngày.

Bảng 5: Thời gian mổ và thời gian nằm viện

\begin{tabular}{|c|c|c|}
\hline $\begin{array}{c}\text { Kích } \\
\text { thước u }\end{array}$ & $\begin{array}{c}\text { Thời gian } \\
\text { mổ (phút ) }\end{array}$ & $\begin{array}{c}\text { Thời gian năm } \\
\text { viện (ngày) }\end{array}$ \\
\hline$<30 \mathrm{~mm}$ & 180 & 8 \\
\hline $30-50 \mathrm{~mm}$ & $205 \pm 112$ & $10,06 \pm 6,24$ \\
\hline$>50 \mathrm{~mm}$ & $272 \pm 141$ & $14 \pm 8,4$ \\
\hline
\end{tabular}

Diến biến sau mố và tình trạng ra viện. 69,86\% bệnh nhân không có biến chứng sau mồ lây u. Có $3,77 \%$ có biến chứng chảy máu ngoài màng cứng, 3,77\% có biến chứng viêm màng não. 7,54\% số ca bệnh sau mổ diễn biến nặng nguy cơ tử vong, gia đình xin bệnh nhân về.

Sau mổ ổn định, bệnh nhân sẽ được chuyển về bệnh viện tuyến tỉnh điều trị hậu phẫu tiếp. 83\% số bệnh nhân sau mổ ổn định thuộc độ 4 , độ 5 . Có 5 bệnh nhân chiếm $9,46 \%$ ra viện ở độ 3 gồm những bệnh nhân sau mổ bị biến chứng suy hô hấp, viểm màng não. $7,54 \%$ số bệnh nhân sau mổ diễn biến nặng, đã được hồi sức tích cực nhưng tình trạng không cải thiện, gia đình xin bệnh nhân về.

Biến chứng sau mổ và điểm GOS lúc ra viện. Nhóm có biến chứng chúng tôi nhận thấy có $43,75 \%$ số bệnh nhân ra viện ở độ 4 , có $31,25 \%$ số bệnh nhân ra viện ở độ 3 . $25 \%$ số bệnh nhân có biến chứng nặng nề ra viện ở độ 2 (gia đình xin về). Tât cả số bệnh nhân sau mổ không có biến chứng đều ra viện ở độ 5 và không có trường hợp nào ra viện ở nhóm 1,2,3.

\section{BÀN LUÂN}

Tuổi và giới. Tuổi mắc bệnh trong nghiên cứu được ghi nhận từ 2 đến 43 tuổi,tuổi trung bình là $12,12 \pm 9$ tuổi.

Trong nghiên cứu này tỉ lệ Nam/ Nữ $=1,52$, điêu này khá tương đồng so với nghiên cứu của Rodriguez và cs với tî lệ $\mathrm{Nam} / \mathrm{Nữ}=1,38 / 1$ nhưng khác biệt nhiều với nghiên cứu của Giordana với tỉ lệ Nam/ Nữ $=2,4 / 1 .{ }^{4}$

Vị trí khối u. Trong nghiên cứu này đa số u xuất hiện ở thuỳ nhộng tiểu não với 83\%. Điều này khác biệt với ngiên cứu của tác giả Rodriguez và cộng sự, tỉ lệ u nguyên bào tủy xuất hiện ở bán cầu tiểu não là $45 \%$, thùy nhộng là $15 \%$, còn lại $40 \%$ là các vị trí khác như não thất IV, khoang dưới nhện, góc cầu tiểu não. Theo nghiên cứu của Hubbard (1989) ${ }^{5}$, tỉ lệ u ở bán cầu tiểu não là $61,76 \%$, thùy nhộng là $38,24 \%$. Có thể nhận thấy sự khác biệt này và chúng tôi đưa ra giả thuyết rằng do cỡ mẫu của chúng tôi chưa thực sự đủ lớn so với các tác giả khác hoặc sự khác biệt về địa lý .

Điểm Karnofsky trước mổ. Điểm Karnofsky trong nghiên cứu trước mổ là $85,68 \pm 12,21$. Kết quả này khác biệt so với kết quả của Vinayak Narayan và cs với điểm Karnofsky $60(60,6 \pm$ $12,9)$. Tuy nhiên nghiên cứu của chúng tôi khá tương đồng với kết quả của Banu Atalar và cs với điểm Karnofsky $>80$ điểm. ${ }^{6}$

Mức độ lấy bỏ u. Trong nghiên cứu này chúng tôi nhận thấy các phẫu thật viên đã cố gắng lấy bỏ u càng nhiêu càng tốt với $73,60 \%$ lấy toàn bộ u, gần hoàn toàn $25,52 \%$. Theo nghiên cứu của Northcott và cs công bố năm 2019 thì tỉ lệ lấy hoàn toàn u chiếm 70- 85\%, khá tương đồng với kết quả của chúng tôi. Tuy nhiên theo nghiên cứu của Haque và cs thì họ chỉ lây được toàn bộ u chỉ với $15 \% .^{7}$

Thời gian phẫu thuật và thời gian nằm viện. Với nhóm u > 50mm thì thời gian phẫu thuật: 272 phút \pm 141 , u $30-50 \mathrm{~mm}$ : 205 phút \pm 112. Chúng tôi nhận thấy trong các trường hợp thời gian phẫu thuật kéo dài có nguyên nhẩn bệnh diễn biến trong mổ như phù não, chảy máu nhiều, u xâm lấn các cấu trúc quan trọng cần phải xử trí xen kẽ phối hợp.

Thời gian điều trị sau mổ từ 5 ngày tới 34 ngày.

Kết quả này không tưng đồng so với kết quả của Lee với 14 ngày điều trị sau mổ ${ }^{8}$, hoăc với Rath, G. P và cs cũng cho thấy thời gian điều trị kéo dài do phẫu thuật có nhiều biến chứng..$^{9}$

Truyên máu trong mổ. Ở phân nhóm u có kích thước > 50mm thì 44,44\% số bệnh nhân cần truyền máu. Có 1 trường hợp u $<30 \mathrm{~mm}$ truyền $450 \mathrm{ml}$ máu. Kết quả này cao hơn so với kết quả của Rath, G.P và cs. ${ }^{9}$

Biến chứng sau mổ. Trong nghiên cứu của chúng tôi có $69,86 \%$ không có biến chứng. Có $3,77 \%$ có biến chứng chảy máu ngoài màng cứng, 3,77\% có biến chứng viêm màng não. 7,54\% số ca bệnh sau mổ diễn biến nặng nguy cơ tử vong, gia đình xin bệnh nhân về. Các tai biến và biến chứng này cũng khá tương đồng với kết quả báo cáo của Mohamed Ali El-Gaidi năm 
2015 với các biến chứng viêm màng não và chảy máu ổ mổ và một số trường hợp tử vong. Các biến chứng khác cũng được ghi nhận nhưng với tần suất ít: rối loạn điện giải, rò dịch não tuỷ, chảy máu sau mổ, nhiễm trùng vết mổ, suy hô hấp.

Kết quả phầu thuật. Trong nghiên cứu này chúng tôi ghi nhân thấy $83 \%$ số bệnh nhân sau mổ có kết quả ổn định thuộc nhóm GOS độ 4, độ 5. Có 5 bệnh nhân ra viện ở GOS độ 3 chiếm 9,46\% gồm những bệnh nhân sau mổ bị biến chứng suy hô hấp, viêm màng não. 7,54\% số bệnh nhân sau mổ diễn biến nặng, đã được hồi sức tích cực nhưng tình trạng không cải thiện, gia đình xin bệnh nhân về.

\section{KẾT LUÂN}

Qua nghiên cứu 53 trường hợp phẫu thuật $\mathrm{u}$ nguyên bào tuỷ tại bệnh viện Việt Đức, chúng tôi thây kết quả $83 \%$ bệnh nhẩn ra viện trong nhóm ổn định (GOS độ 4, 5); 9,46\% ra viện GOS độ 3; $7,54 \%$ ra viện với diễn biến nặng sau mổ.

Các biến chứng sau mổ chúng tôi thu nhận được qua nghiên cứu gồm có chảy máu ngoài màng cứng, viêm màng não, suy hô hấp, rối loạn điện giải, rò dịch não tuỷ, nhiễm trùng vết mổ và đã được xử trí kịp thời và chính xác.

\section{TÀI LIÊU THAM KHẢO}

1. Tuyển BQ. Bệnh học thân kinh, sau đại học. Bệnh học thần kinh, sau đại học Nhà xuất bản quân đội nhân dân. 2003:207-224.

2. Millard NE, De Braganca KC. Medulloblastoma. Journal of Child Neurology. 2016;31(12):1341-1353.

3. Bavle A, Parsons DW. From One to Many: Further Refinement of Medulloblastoma Subtypes Offers Promise for Personalized Therapy. Cancer Cell. Jun 12 2017;31(6):727-729.

4. Poussaint TY, Rodriguez D. Advanced neuroimaging of pediatric brain tumors: MR diffusion, MR perfusion, and MR spectroscopy. Neuroimaging Clin N Am. Feb 2006;16(1):169-92, ix. doi:10.1016/j.nic.2005.11.005

5. JL H. Adult cerebellar medulloblastomas: the pathological, radiographic, and clinical disease spectrum. JNeurosurg. 1989; Vol 70:536-544.

6. Atalar B, Ozsahin M, Call J, et al. Treatment outcome and prognostic factors for adult patients with medulloblastoma: The Rare Cancer Network (RCN) experience. Radiother Oncol. Apr 2018;127(1):96-102.

doi:10.1016/j.radonc.2017.12.028

7. Haque $\mathbf{W}$, Verma $\mathbf{V}$, Brian Butler $E$, Teh BS. Prognostic role of chemotherapy, radiotherapy dose, and extent of surgical resection in adult medulloblastoma. Journal of Clinical Neuroscience. 2020;76:154-160. doi:10.1016/j.jocn.2020.04.002

8. Lee ST, Lui TN, Chang CN, Cheng WC. Early postoperative seizures after posterior fossa surgery. J Neurosurg. Oct 1990;73(4):541-4. doi:10.3171 / jns.1990.73.4.0541

9. Rath GP, Bithal PK, Chaturvedi A, Dash HH. Complications related to positioning in posterior fossa craniectomy. J Clin Neurosci. Jun 2007;14(6):520-5. doi:10.1016/j.jocn.2006.02.010

\section{NGHIÊN CỨU ĐẶC ĐIỂM LÂM SÀNG VÀ KẾT QUẢ ĐIỀU TRI Ở BÊNNH NHÂN NHỒI MÁU NÃO Có RUNG NHĨ}

\section{TÓM TẮT}

Đặt vấn đê: Trên thế giới, đột quỵ não là nguyên nhân gây tử vong thứ ba sau bệnh tim thiếu máu cục bộ và ung thư. Tại Việt Nam, ước tính hàng năm có khoảng 200.000 người bi đột quy. Theo đánh giá của Tổ chức $Y$ tế Thế giới (WHO, 2015), đột quy là nguyên nhân chính gây tử vong ở Việt Nam $(21,7 \%)$ với số lương bênh nhân tử vong hàng năm là 150.000 (Health Grove, 2013). Rung nhĩ là rối loạn nhịp tim kéo dài thường gă̆p nhất làm tăng tỷ lệ mắc bệnh, tử vong và gánh nặng kinh tế xã hội ở bệnh nhân đột quy. Tại Việt Nam, hiện chưa có nhiều nghiên cứu

\footnotetext{
${ }^{1}$ Trường Đại học Y Hà Nội

${ }^{2}$ Bênh viên Bach Mai

Chịu trách nhiệm chính: Võ Hồng Khôi

Email: drvohongkhoi@yahoo.com.vn

Ngày nhận bài: 22.10.2021

Ngày phản biên khoa họ: 20.12 .2021

Ngày duyệt bài: 30.12.2021
}

\section{Võ Hồng Khôi ${ }^{1,2}$, Lê Thị Nga ${ }^{1}$}

đánh giá về đăc điểm lâm sàng và kết quả điều tri ở bệnh nhân nhồi máu não có rung nhĩ. Muc tiêu: Nhận xét đắc điểm lâm sàng và kết quả điều trị ở bệnh nhân nhồi máu não có rung nhĩ. Đối tượng và phương pháp: Nghiên cứu mô tả tiến cứu 55 bệnh nhân nhồi máu não có rung nhĩ điều trị nội trú tại Trung tâm Thần kinh, Bênh viện Bạch Mai từ tháng 5 năm 2019 đến tháng 7 năm 2020. Kết quả: Nhồi máu não ở bệnh nhân rung nhĩ có triệu chứng lâm sàng trong thời kỳ toàn phát cũng tương tự như nhồi máu não ỡ các bệnh nhân khác, triệu chứng lâm sàng hay gặp nhất là liệt nửa người và rổi loạn ngôn ngữ (chiếm lần lượt $85,5 \%$ và $63,6 \%$ ). Đa số bệnh nhân có mức độ hồi phục lâm sàng kém (điểm mRS tại thời điểm xuất viện $\geq 3$ chiếm $65,5 \%$ ).

Tư khóa: nhồi máu não, rung nhĩ, triệu chứng lâm sàng, kết quả điều trị.

\section{SUMMARY \\ CLINICAL FEATURES AND OUTCOME IN ISCHEMIC STROKE PATIENTS WITH}

